\title{
War, Anxiety, and Hope in American Sheet Music, 1914-1917
}

\section{CHRISTINA GIER}

Soon after hostilities began in Europe in August 1914, the American government proclaimed their neutrality in the conflict. As former President Taft wrote of the European chaos, "It is a cataclysm... [and] we have every reason to be happy that we are able to preserve strict neutrality in respect to it." ${ }^{1}$ In the following three years, deep divisions over American neutrality versus military involvement occupied the discourse of the country. President Wilson's party, the liberal internationalists, expressed fear that adopting an offensive stance in the conflict would militarize the nation and threaten the cherished American values of liberty and democracy. Instead of building a conscripted army, Wilson looked to the public for their strength as democratic citizens to counter the belligerency overseas. As he stated in a speech in late 1915, "...we are asking for a trained citizenry which will act in the spirit of citizenship and not in the spirit of military establishments." ${ }^{2}$ The government maintained this anti-involvement course throughout the years of official neutrality, and businesses flourished from their sales to the warring parties. Some had hoped that Wilson's early rhetoric of diplomacy and mediation between belligerents would succeed, but after these efforts failed and the war entered its second year, many feared that the horrors of the battlefield would come to America. ${ }^{3}$ An important but unaddressed venue for the expression of these fears was the sheet music in circulation from 1914 through 1917. This article examines a selection of these popular songs in which the crisis and anxiety of impending war is starkly reflected and brings attention to how these popular songs engaged in a significant personal discourse of anxiety and hope in response to the devastation in Europe and unknown threat to America. As I show, songs promoting "preparedness" (the argument to increase American military readiness) appeared in 1916 and echo growing political and military arguments. However, the antiwar argument continued until April 1917 when the Americans officially joined the fight. Beginning in 1914 with the euphoric song "We Take our Hats off to You, Mr. Wilson!” I trace sheet music's response to the war through several anxious and hopeful pacifist songs, such as "The Heart of the World" (1915), "When Mothers Rule the World" (1915), and "I Didn't Raise My Boy to Be a Soldier" (1915), supportive songs, such as "I'd be Proud to be the Mother of a Soldier" (1915), and the stoic "Old Glory, a Song of Preparedness" (1916). I discuss the way the song lyrics and cover illustrations utilize tropes of the resolute Father and weeping Mother, while other lyrics reveal social tensions between classes. After the idea of preparedness enters the national consciousness in 1916, we see

\footnotetext{
${ }^{1}$ William Dudley, ed. World War I: Opposing Viewpoints (San Diego: Greenhaven Press,1998), 24. The following books also provide historical background for this article. Ross A. Kennedy, The Will to Believe (Kent, Ohio: Kent State University Press, 2009), Robert H. Zieger, America's Great War: World War I and the American Experience (Lanham and New York: Rowman and Littlefield Publishers, 2000), David Kennedy, Over Here: The First World War and American Society (New York: Oxford University Press, 1980).

${ }^{2}$ Kennedy, The Will to Believe, 4.

${ }^{3}$ According to historian Robert Zieger, Wilson only presented a "pro forma" offer of mediation in the fall of 1914, and when the attempted mediation had little impact, Wilson "prayed to God" for peace. Zieger, America's Great War: World War I and the American Experience, 20.
} 
both parental symbols become more overtly militant, with Mother and Father united in a psychological preparation for war.

In 1914 Tin Pan Alley and other sheet music publishers across the nation prospered selling sentimental songs about love as they always had, but as the war continued an increasing number of songs responded to it. ${ }^{4}$ I have selected sheet music based on date and topic that shows a thematic link to the war and not only offers a perspective on the beliefs and preoccupations of the lyricists and composers but also provides a lens into the private musical experience of the people who bought it. The venue for the performance of these songs was not in the bright lights of the vaudeville stage-indeed most of these songs never achieved any fame-but rather the personal environment of the home, and a private context of family and friends engaged in music making and conversation.

This sheet music was written by white Americans for a white middle-class urban market rather than new immigrants or African Americans. As Craig Roell shows in his book on the piano in America, by 1915 the majority of these middle-class families had a piano in their homes. Indeed, he notes, there was even an expansion in sales in the first decades of the twentieth century when American piano manufacturers sold around 300,000 pianos a year, with a notable increase in $1916 .{ }^{5}$ Even though few records exist indicating the volume of sheet-music sales during these years, the sheet music itself acts as a historical document that testifies to a musical practice through which the complex and intractable issues of peace and war could be exteriorized and expressed.

As Nicholas Tawa has pointed out, in the history of the Tin Pan Alley song tradition, "language is kept plain, graphic, relevant and concrete. Abstract and unusual references are avoided." And indeed, the texts of these songs revolve around plain and concrete symbols that shape and influence the domestic discourse of war through the icons of Mother, Father, and Son. In fact, the writers of these songs paid great attention to gender roles-a tendency that, in addition to the sheer potency of these basic familial symbols might also point to the centrality of home and family to their market. The Father and Mother figures are often polarized, with the Mother standing for the antithesis of war, and a marker for home and nation-as sweetness opposed to brutality-and the Father representing the leader in charge who shows the way forward to solve any crisis. ${ }^{7}$ As the threat of war with Germany increased and preparedness gained ground, we see a change in the discourse of Mother and Father in these songs. Tropes shift from the Father represented by the wise president as a guardian of peace and the Mother as protective and gentle symbol, to the more overtly pro-engagement stance of both.

\footnotetext{
${ }^{4}$ Vogel and Parker offer bibliographical catalogues, and Vogel specifically of songs published during the war. Frederick G. Vogel, World War I Songs: A History and Dictionary of Popular American Patriotic Tunes with over 300 Complete Lyrics (Jefferson, NC: McFarland and Company, 1995); Bernard Parker, World War I Sheet Music: 9,670 Patriotic Songs Published in the United States, 1914-1920, with More Than 600 Covers Illustrated (Jefferson, NC: McFarland, 2007). Jasen and Tawa offer book-length historical background on the broader phenomenon of Tin Pan Alley over the years. Frederick G. Vogel, World War I Songs: A History and Dictionary of Popular American Patriotic Tunes with over 300 Complete Lyrics (Jefferson, NC and London: McFarland and Company, Inc., 1995), Nicholas Tawa, The Way to Tin Pan Alley: American Popular Song, $1866-1910$ (New York: Schirmer Books, 1990), David A. Jasen, Tin Pan Alley: The Composers, the Songs, the Performers and Their Times (New York: Donald I. Fine, Inc., 2003), Bernard Parker, World War I Sheet Music : 9,670 Patriotic Songs Published in the United States, 1914-1920, with More Than 600 Covers Illustrated (Jefferson, N.C.: McFarland, 2007).

${ }^{5}$ Craig H. Roell, The Piano in America, 1890-1940 (Chapel Hill: The University of North Carolina Press, 1989 ), 70.

${ }^{6}$ Tawa, The Way to Tin Pan Alley: American Popular Song, 1866-1910, 95.

${ }^{7}$ Jean Bethke Elshtain, Women and War (New York: Basic Books, 1987), 4.
} 
In 1914 the successful New York sheet music firm Leo Feist published a song written by Blanche Merrill called "We Take our Hats off to You, Mr. Wilson!" conveys patriotic admiration for the president's non-engagement policies. The first verse reads,

You are one of Uncle Sammy's boys, You have no use for any noise,

You've won every Yankee heart from coast to coast.

Greater than a gladiator, You're the world's big mediator,

Of you this whole United States can boast, We're glad you belong to us.

We'd trust you in any kind of fuss, We're glad you belong to us.

In these lyrics, Wilson is the mediator, and the tempo is a march with the bass line a marcato. The piano introduction carries a strident tone in the opening with repeated rhythmic gestures in $\mathrm{C}$ major, and these musical markers of strength are used despite the fact that the strength in question is not physical but instead diplomatic. The musical cues help the lyrics convey a commander in charge (one who could choose to fight or not to fight), and they clarify Merrill's high opinion of Wilson's leadership and democratic ideals, as well as of his efforts to mediate between belligerents. The melody spans the upper pitches of the C-major scale with the same ease that Merrill wants to attribute to the leader. The chorus plays with syncopation on the line "we take out hats off to you" with an off-beat accent and fully diminished seventh chord on "off" as the harmony heads towards the dominant. The rhythm continues to play with this offbeat emphasis on the lines "You're the man of the ho-ur, You stood like a tow-er," and the rhythmic drive is infectious (Example 1). According to Robert Zieger, however, Wilson only presented a "pro forma" offer of mediation in the fall of 1914, and when the attempted mediation had little impact, Wilson then admitted he could do no more and "prayed to God" for peace. ${ }^{9}$ Likely written before any news of the futility and ultimate failure of his early diplomatic efforts, the chorus cheers his labours: "Your pen is greater than the sword, We take our hats off to you!" Merrill's song is an example of the Father rhetoric: trust the leader, who will guide us towards the right and just. Have no fear, everything will work out.

Example 1. "We Take Our Hats off to You Mr. Wilson!" (1914) chorus, music and words excerpt, by Blanche Merrill.

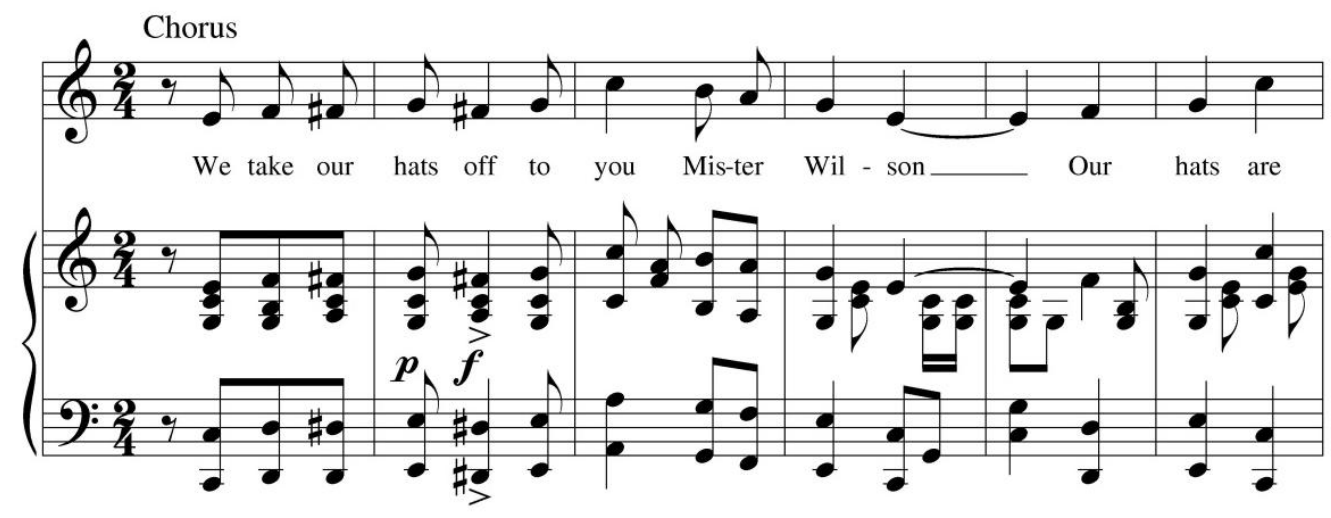

\footnotetext{
${ }^{8}$ Merrill had a career writing lyrics; she is known for her hit songs for singer Eva Tanguay in 1910, and she would later work as a lyricist with the performer Fannie Brice and write for Betty Boop, among other Hollywood productions. See http://www.imdb.com/name/nm0581264/ (accessed January 6, 2011); and Jasen, Tin Pan Alley: The Composers, the Songs, the Performers and Their Times, 387.

${ }^{9}$ Zieger, America's Great War: World War I and the American Experience, 20.
} 


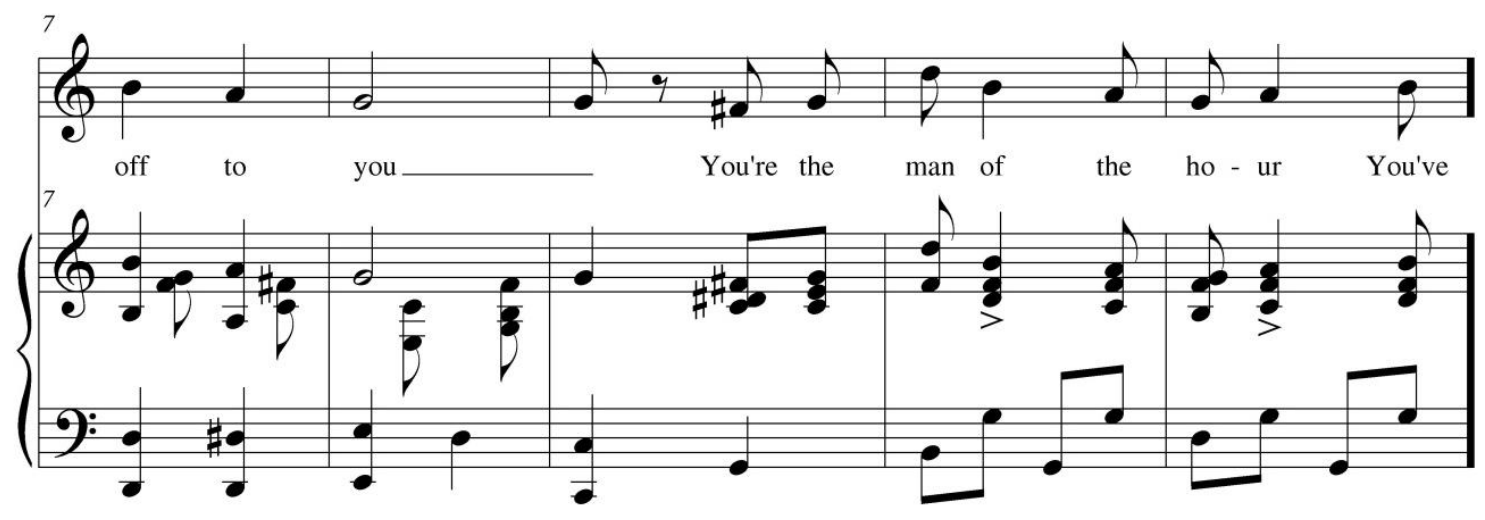

During the war, the pacifist movement inspired at least four thousand conscientious objectors to refuse the draft and risk prison. ${ }^{10}$ David Patterson tells us there were at least forty-five new peace groups that had organized between 1900 and 1914, but that the pacifists in the early 1900s, unlike later peace activists during the Vietnam War era, were not reacting directly to an American conflict. Instead, these peace organizations tended to be Anglo-Saxon and Protestant elites who were driven by an "unquestioned faith in inevitable moral progress." 11 They saw the threat of war as a relic of an earlier age when men could not rationally decide disagreements. The broad antiwar sentiment in 1915 influenced several songwriters to write songs that called for peace. The lyrics of some of these songs center on the Mother as promoter of harmony and goodness. It is not far-fetched to presume that the commercial focus of the writers and publishers producing this sheet music was for women playing the piano at home with their families. ${ }^{12}$

The song "The Heart of the World" from 1915 by George McConnel humanizes "Mother Earth" and rhetorically connects the trope with peace. In this song the level of despondency in the words is notable; there is a sense that mankind will never be able to solve the problems caused by the war. The first verse reads,

If Old Mother Earth were human,

Her heart would be sad today

When men start to fight and blight with

Their might,

She must turn her head away.

The verse is in common time; however, the chorus changes to a triple division of the beat in 12/8, which gives the section a gentle rocking feeling. ${ }^{13}$ This is not a comforting feeling though because there is a dirgelike despondency to the line. At the end of the chorus, the final words dejectedly sing "nobody seems to care," while the harmony briefly hints at E-flat minor with C-flat to cement the helpless tone. After this momentary switch to minor, the pain of the song seems to yield to excess in the final accented E-flat major

\footnotetext{
${ }^{10}$ Robert and Helen Michalowski Cooney, The Power of the People (Culver City, CA: Peace Press, 1977), 44.

${ }^{11}$ David S. Patterson, "Citizen Peace Initiatives and American Political Culture, 1865-1920," in Peace Movements and Political Cultures, ed. Charles and Peter Van den Dungen Chatfield (Knoxville: University of Tennesssee Press, 1988), $192,94$.

${ }^{12}$ See, for example, the discussion in Roell, The Piano in America, 1890-1940, 14-28.

${ }^{13}$ As Tawa might suggest, the metric shift gives the song a semi-artistic sensibility, and here it is in the context of expressing great sadness. These musical details indicate a more upper-class style. Tawa, The Way to Tin Pan Alley: American Popular Song, 1866-1910, 174-215.
} 
chord marked triple fortissimo. These chromatically altered phrases and extreme dynamics compellingly express pain and sorrow to persuade the listener (Example 2).

Example 2. "The Heart of the World" (1915) by George B. McConnell arranged by Frank Black. Final chorus, measures 12-18.
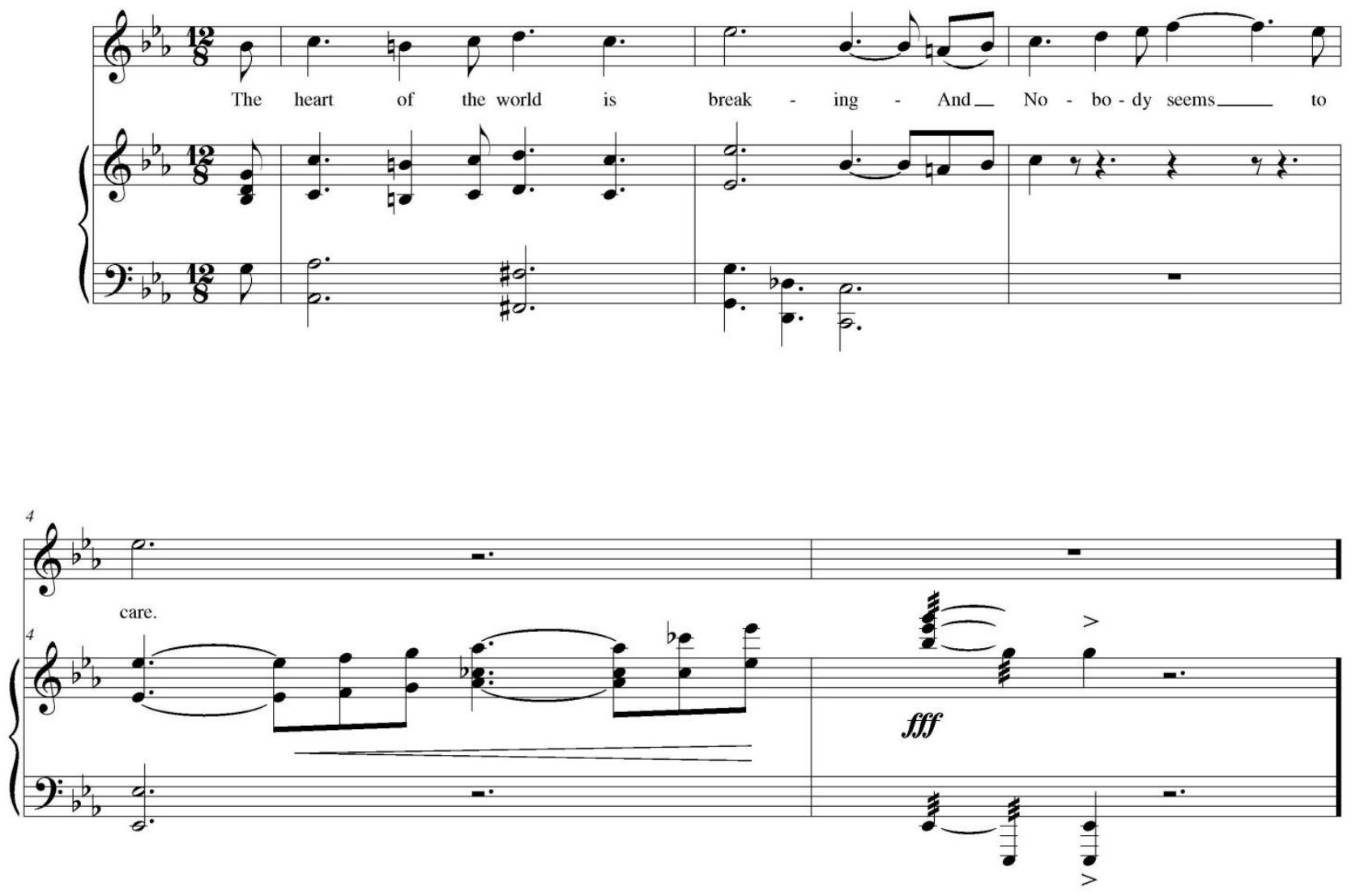

The song "When Our Mothers Rule the World" from 1915 presents a pro-woman sentiment and appears to be aimed at women buyers in particular. It was written by Alfred Bryan and composed by Jack Wells, two songwriters who would later collaborate on successful sheet music supporting the war effort, such as "Joan of Arc They are Calling You" (1917). ${ }^{14}$ In "When Mothers Rule" the songwriters accentuate the idea of the feminine and paint mothers as unique arbiters of peace. The sheet music indicates it was published in Detroit and New York by successful publisher Jerome H. Remick and Co., which gives some idea of its broad distribution. The cover image illustrates a young mother looking fretfully at the ravages of war over the horizon while she sits with her children (Figure 1). To a repeated melodic pattern, the first verse sings,

Camp fires are gleaming, Soldiers are dreaming, Sobs one lonesome lad,

I left her sighing, I left her crying, She was all I had.

When men rule our nations, Sweethearts and mothers must cry

Men in their madness, caused all the sadness

\footnotetext{
${ }^{14}$ Wells and Bryan's "Joan of Arc" is discussed in Christina Gier, "Gender, Politics, and the Fighting Soldier's Song in America During World War I," Music and Politics 2, no. 1 (2008). Alfred Bryan was a well-known lyricist for Tin Pan Alley, who continued to write hits for decades. Jasen, Tin Pan Alley: The Composers, the Songs, the Performers and Their Times, 442.
} 

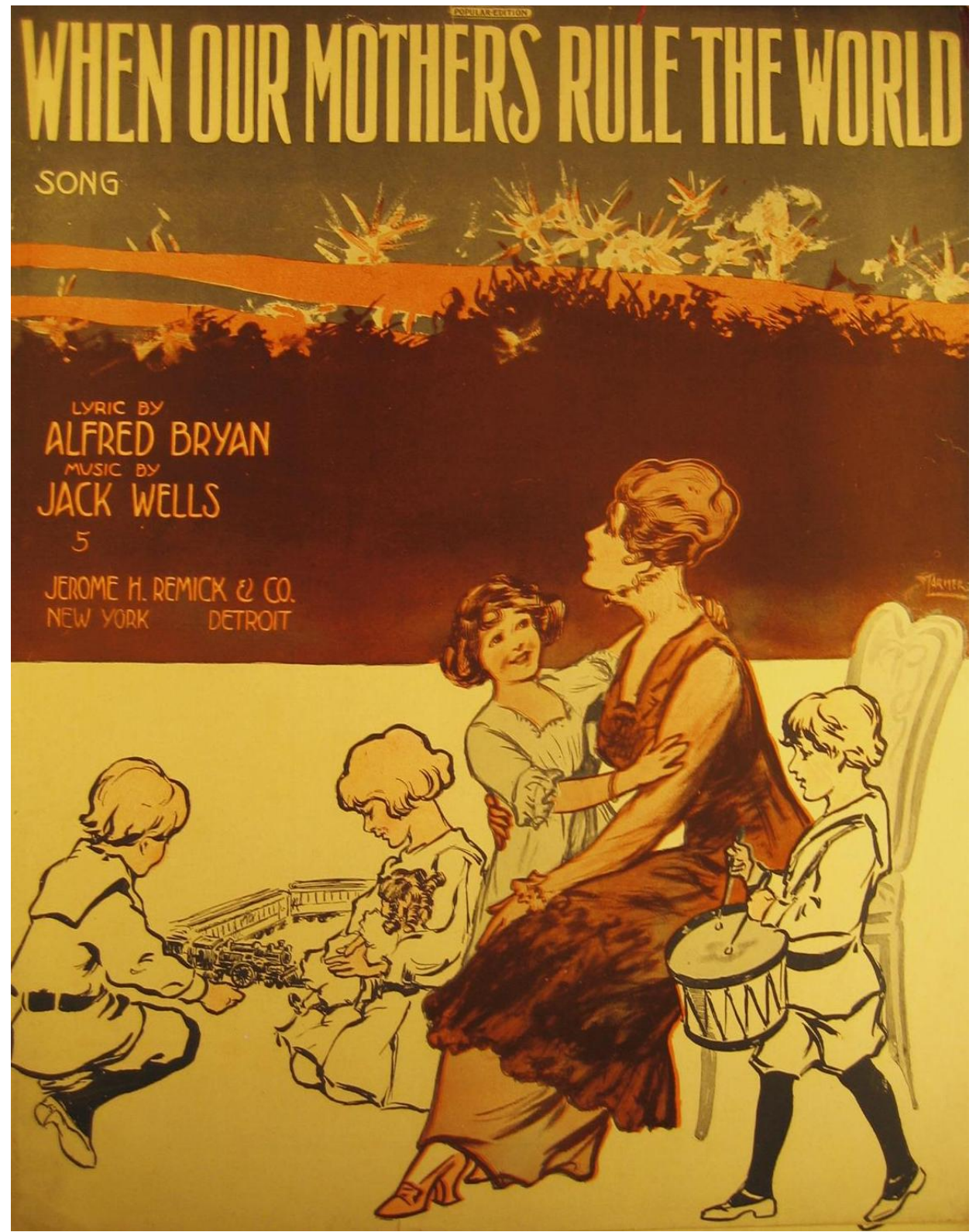

Figure 1. Cover image to "When Our Mother's Rule the World” (1915). 
The fact that two men wrote the song weakens the seemingly brazen political character of the phrases "When our Mothers rule" and "men in their madness." The rhyme between "madness" and "sadness" augments the simplicity of the purported truth of mothers' strength imparted by the song. The chorus goes on to look forward to the fictitious future when mothers are in charge.

There would be no sweethearts crying, If our mothers had their say

There would be no lovers dying[,] In the trenches far away

There would be no armies marching, And no battle flags unfurled

Let us kneel and pray[,] We'll live to see the day

When our Mothers rule the world.

The title phrase that ends the chorus would have appeared ludicrous to many men, and perhaps even hilarious, but there is a voice of fear resounding from the words. It is a fear expressed in hyperbole, as though the men were boys, and mothers will make everything right. Here the icon of Mother carries the dream of an imagined resolution.

Another pacifist song from 1915 presents a potent call for peace by recalling the death of a father in a past war. "Lay down your arms" (1915) was written by Louise Small and composed by Charles James. The verses focus on the sorrow of mothers whose sons become soldiers and soldiers who have died as the reasons not to go to war. The second verse concludes with the lines, "Now if years ago the mother's [sic] had their say/ They'd have their darling boy with them today." The mother weeps about the "son she could not save." In 1915, it is certain that the writer is not referring to American mothers' sons who had gone to Europe to fight, or even sons who fought in the 1914 Mexican conflict, because the U.S. army was so small then, with only 200,000 soldiers. They are generalizing about the suffering of war and perhaps speaking to experiences of loss in the Civil War. These words express a deep anxiety and fear rooted in the collective memories of loss and devastation. The underlying antiwar message pivots around the figure of the grieving mother. The chorus sings,

Lay down your arms, my boy, my boy, Let us have universal peace.

God only knows there has been bloodshed enough, It's time the shot and shell should cease

Mothers are weeping day by day, For their pride and joy,

Your father lost his life that way, If he was [here] right now he'd say

Put that sword and gun away, Lay down your arms my boy.

The melody encapsulates these calls for peace in tidy phrases that repeat the rise of a fourth on the words "My boy, my boy" and in the repeated stanza on "day by day," and the melody rises to a high E on "joy" and again for the command to "put that sword and gun away." Repeated melodic arches construct the pacifist message through musical parallels to the text. Song lyrics like these are grounded in the idea of radical differences between the sexes, and the view that women naturally had no desire or inclination to fight.

The lyrics to "It's a Long Way to Berlin" communicate a more overtly political message. The subtitle is "The Song of the Soldier and Sailor," though there is no record of this song's use by the military. Published in 1915 in New York with an image of a lion crying on the cover, it is an excellent example of self-promotion in song writing of this period (Figure 2). The cover has much more information on it than typical covers from standard publishing houses. Francis J. Lowe wrote, composed, and published this song, and as he indicates, his title self-consciously plays off the most popular British marching tune of the First 
World War, "It's a long, long way to Tipperary." Lowe claims to have sold over a hundred thousand copies, and he dedicates it to another self-made man he admires, Henry Ford. An advertisement for another of his songs entitled "Arc of Peace" accompanies the weeping lion with the phrase "Give us a little Cheer." The weeping lion possibly refers to the songwriter himself, since "lion" is der Löwe in German. Whether the sales numbers are accurate or not, Lowe's entrepreneurial spirit shows. He is not mentioned in current sources on early twentieth-century American songwriters, so he likely did not make any notable impression in the field. ${ }^{15}$ The cover announces the importance of the song before we even see the music or lyrics. Lowe is trying to say something provocatively; the song itself stands as an individual's discerning statement about current events.

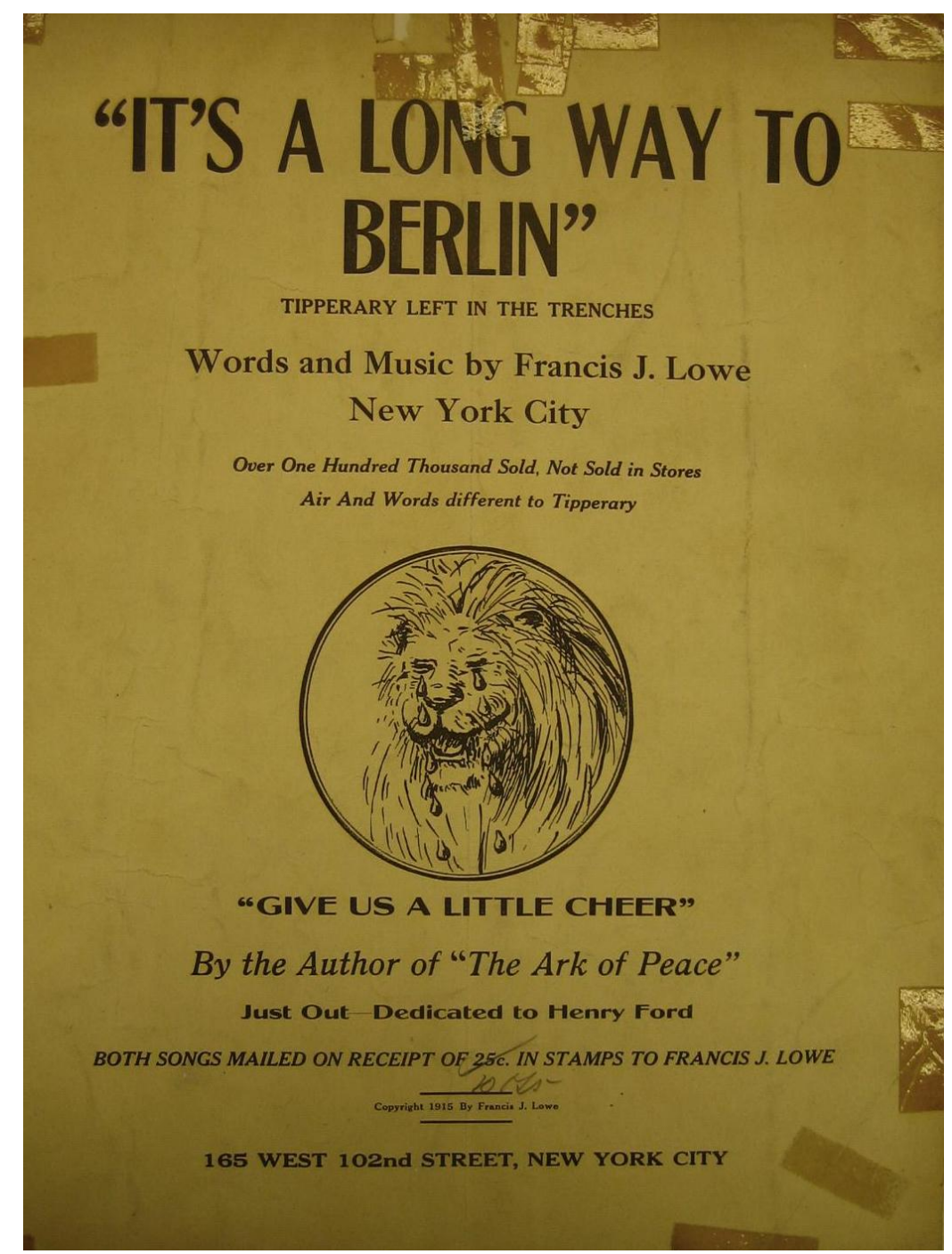

Figure 2. Cover for "It's a Long Way to Berlin" (1915) by Francis J. Lowe.

\footnotetext{
${ }^{15}$ Phillip and Michael Lasser Furia, America's Songs: The Stories Behind the Songs of Broadway, Hollywood and Tin Pan Alley (London, New York: Routledge, 2006), Jasen, Tin Pan Alley: The Composers, the Songs, the Performers and Their Times.
} 
Lowe's musical style establishes his serious purpose with strong broad rhythms and minimal decoration in his introduction. The melody is easy to sing, within an octave, and is not related to the "Tipperary" melody in any notable way (nor does the later American war song "It's a Long Way to Berlin, but We'll Get There" from 1917 show any relation to it). The lyrics begin with the "fateful" August of 1914 in the first verse and then mention "Our Little Tommy Atkins," which was a nickname for the generic British soldier, who will have to, as Lowe writes, "cut out the boose [sic]." $\mathrm{He}$ emphasizes that as the average man, the soldier will have his life turned upside down by events beyond his control, and then in the second verse he blames the aristocracy of Europe for the troubles: the "Lords and Dukes" who "made an awful noise" that was heard "way out in China."

The third verse is of interest because he directly mentions antiwar activities happening in the U.S.:

We tried our best to stop them[,] Our work is very slow,

Some erected a peace palace[,] With old Carnegie's dough;

But the widows and the orphans will sob and many a tear,

Unless fighting men will listen to Woodrow Wilson here.

In this verse, Lowe wants to communicate at least three points: the situation of suffering (especially of women and children), Wilson's potential to stop it, and the sad failure of "Carnegie's palace" initially to negotiate a truce. The Carnegie Foundation was considered one of the more conservative organizations for peace in 1915 because they decided that they could not advocate an end to the war but rather the resolute military defeat of Germany and the subsequent establishment of ways to build "international relations based upon cooperation and judicial principles." ${ }^{17}$ In fact, the Carnegie Foundation encouraged pacifist organizations to desist from protest in 1915 and instead focus on postwar plans for a peaceful resolution because, in their view, German belligerency was untenable. Organizations such as the American Peace Society and International Peace Bureau agreed with this approach. These two groups were led by Harvard University President Lawrence Lowell, who founded the more conservative Association to the League to Enforce Peace in 1915. Its program concerned ways to influence key decision makers in government, and it likely succeeded in this goal given that the leadership also included people such as former President William Howard Taft. ${ }^{18}$ Lowe's song, though it does not match the sophistication of statements and actions by these men, effectively delivers the same general political message in a form accessible to people less likely to hear or read speeches by Lowell or Taft. His lyrics adopt the voice of the Father and echo Wilson's calls for settlement and Carnegie's support for a managed peace. These examples of sheet music show involvement with the public debate on issues of war and peace within the private context of singing and music-making in the home.

The principles of pacifism found expression in numerous songs but one song in particular enjoyed notable popularity. The song "I Didn't Raise My Boy to Be a Soldier" was first published in 1915 by Leo Feist, Inc. Subtitled "A Mother's Plea for Peace," this song was composed by Alfred Piantadosi. Merrill also shares credit for the song with Ernie Erdman and Fred Fisher. With lyrics by Alfred Bryan, the song has the inscription "respectfully dedicated to mothers everywhere." Here the Mother-Son relationship

\footnotetext{
${ }^{16}$ The Duke of Wellington gave the English soldier this generic name in 1843, though as John Laffin reports, other sources show that it was in use at least a century before. John Laffin, Tommy Atkins: The Story of the English Soldier (Gloucestershire: Sutton Publishing Limited, 1966; 2004), vii.

${ }^{17}$ John Whiteclay Chambers, To Raise and Army: The Draft Comes to Modern America (New York: The Free Press, 1987), xlv.

${ }^{18}$ Ibid., xlvi.
} 
finds primary importance. Historian Bryan Farwell reports that "I Didn't Raise My Boy" was the most popular song on Tin Pan Alley in January 1917. ${ }^{19}$ According to Glenn Watkins, the song sold 700,000 copies in 1915, and a recording of it was made, together with Irving Berlin's "Stay Down Here Where You Belong," in 1916. As Watkins points out, the song continued to sell until April 1917 when the U.S. declared war on Germany. As he tells us, recently published pro-neutrality songs, such as "If They Want to Fight, All Right, But Neutrality is My Middle Name" became unpopular. ${ }^{20}$ We can presume this was also true for "I Didn't Raise My Boy."

The musical style is catchy, which perhaps explains the numerous performances, recordings, and versions of this song over the two years it was in publication. The song plays with the circle of fifths in the introduction and then the piano line shifts into a vamping phrase. The words are serious at first and move through dotted rhythms and running eighth notes:

Ten million soldiers to war have gone,

Who may never return again,

Ten million mothers' hearts must break,

For the ones who've died in vain

"Ten million men" is of course symbolic hyperbole that the writers use to magnify a mother's sorrow in this memorable song. Her relationship to her son is central to these lyrics, as the chorus sings, "Who dares to place a musket on his shoulder, / To shoot some other mother's darling boy?" The song is quite well composed. The writers employ syncopation articulated in the word "never," as in the phrase "may never return again" in the first verse, and the syncopation is emphasized by an accent in the piano part (Example 3). After this, even eighth notes carry the chorus to cement the title phrase with a strong accent in the piano on "soldier," and the singer emphasizes the importance of the word with a half note.

Example 3. "I Didn't Raise My Boy to Be a Soldier" (1915) measures 12-19.

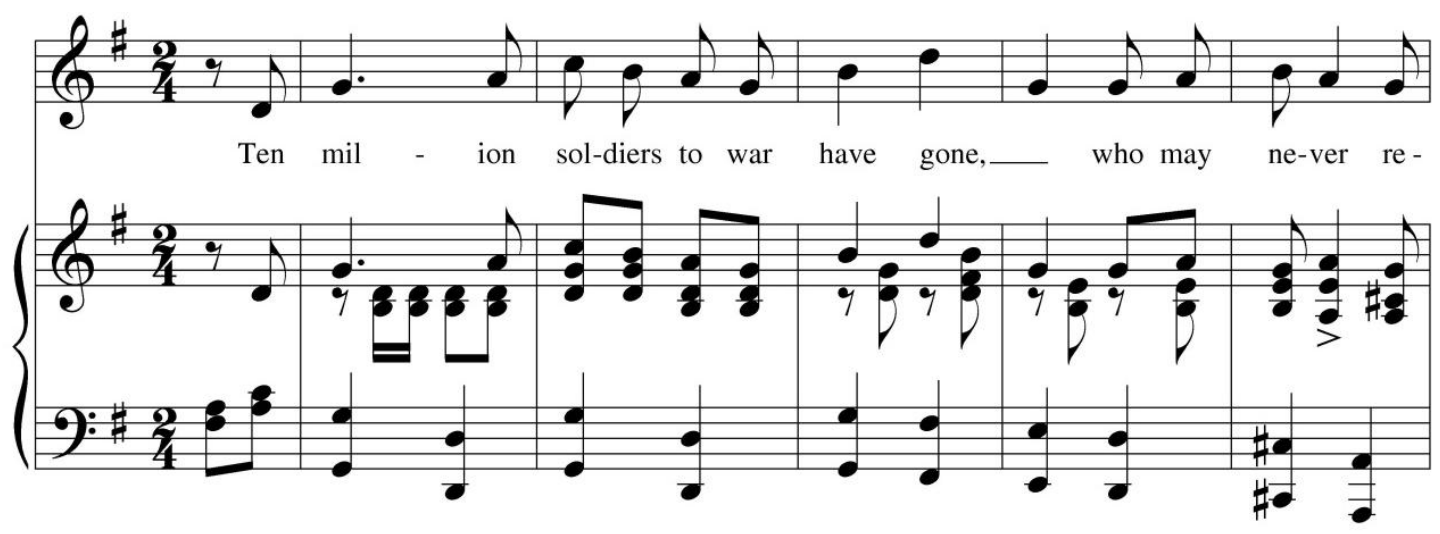

\footnotetext{
${ }^{19}$ Byron Farwell, Over There: The United States in the Great War 1917-1918 (New York London: W.W. Norton and Company, 1999), 50.

${ }^{20}$ Glenn Watkins, Proof through the Night: Music and the Great War (Berkeley: University of California Press, 2003$), 249$.
} 
Example 3 (continued).
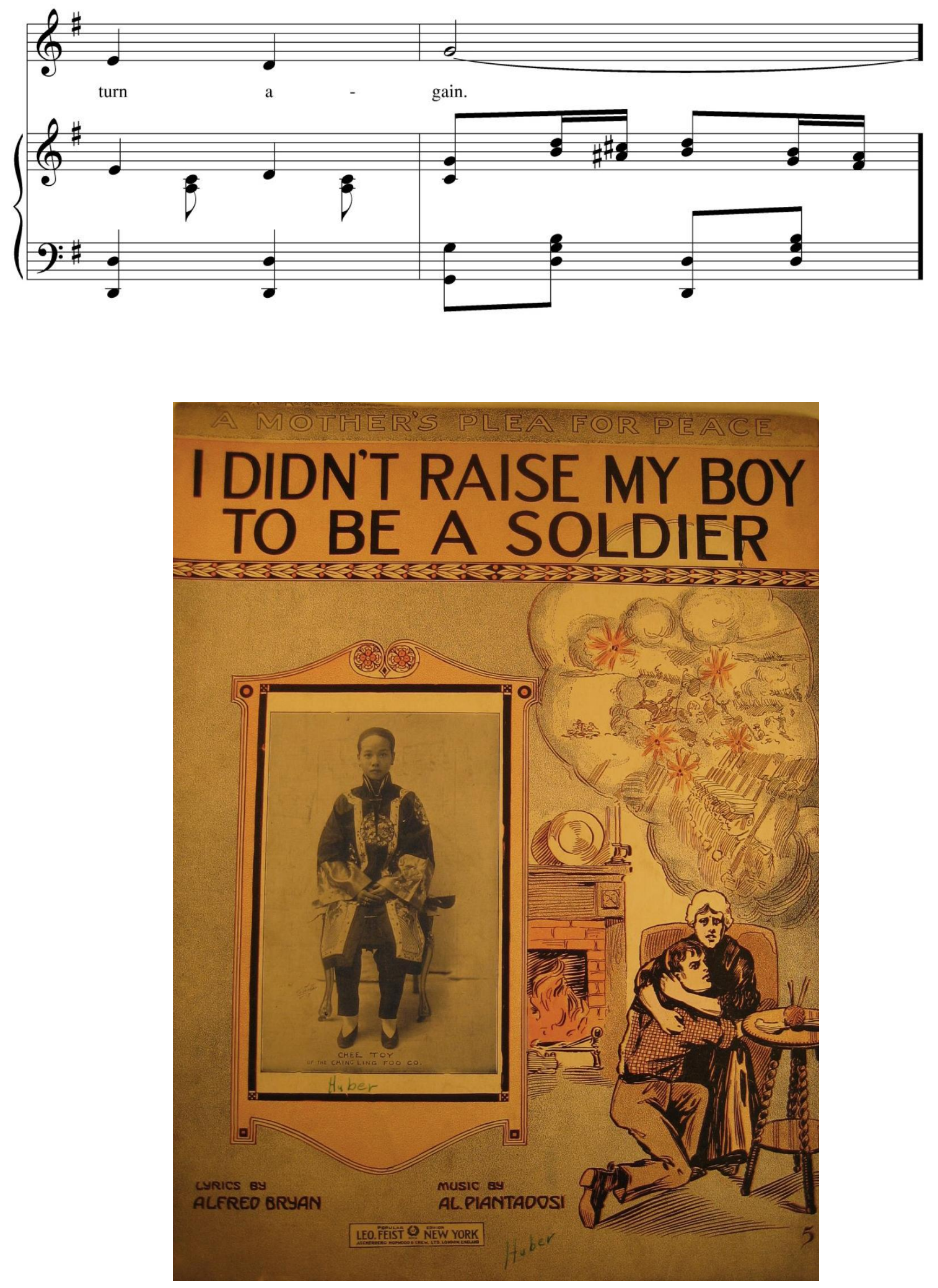

Figure 3. Chee 'Toy' of the Ching Ling Foo Company cover image to "I Didn't Raise my Boy to be a Soldier" (1915). 
The various cover images produced for the numerous editions of this song are of interest and speak to different performances and also a large variety of performers. Unlike the other songs discussed here, these different cover images reveal that this song had numerous vaudeville stage performances. The song was apparently so well liked that numerous editions were published with different performers featured on each cover. The cover image from 1915 presents an inset of the popular vaudeville singer Ed Morten, who premiered the song. Another copy shows the image of "Chief Tendehoa" in the inset, and while it is unclear whether he was an actual chief or not, he is dressed in traditional wear and posing as Native Americans would have when they performed at fairs or expositions in the early twentieth century. It is also not clear whether he actually sang the song on stage. Significantly, he bears a cross on his chest woven into the material of his garment to show that he is not a threat; he is a Christian and a peacemaker. A second image of significance is the cover image of a young Chinese performer named Chee Toy of the Ching Ling Foo Company (Figure 3). Both of these covers show performers from underrepresented classes of American society, who did not have much of a political voice, though as artists they would have been known from vaudeville circuits. Other copies of "I Didn't Raise My Boy" show various white performers, such as the singer Mae Francis (who found fame with this song), the "Street Urchins" Ruby Raymond and Fred Heider, and the American Comedy Four, a group with some in blackface. Even given the spectacle and fun of its performances, however, the song joins in the expression of anxiety and isolationism projected by other songs, such as "The Heart of this World." The war was a deeply fearful event to many Americans as these songs show.

In 1915 a division began to form in the public debate about the war, between those advocating military preparedness (readiness to go to war) and those pacifists who perceived preparedness as a threat and a prelude to war. The anxiety about war is expressed by journals such as The Nation in terms of writers' fear of the transformation of individuals into militarized "automata." ${ }^{11}$ Meanwhile the preparedness camp, supported by men such as Leonard Wood and Theodore Roosevelt, called on the U.S. to start preparing for possible combat, and supporters began training at places like Plattsburg, New York. Roosevelt and other Republican progressives had made arguments for preparedness when the war began in 1914, and their arguments grew even louder in 1915 after public outcry over the Lusitania sinking. In February 1916, Wilson acknowledged the need to strengthen the navy. Advocates for greater preparedness called for an increase in army size and Universal Military Training (UMT), which Wilson resisted. In 1916 the administration proposed that an additional 250,000 men be trained for the regular army as a bulwark against potential military aggression. A staunch supporter of this plan, Roosevelt wanted to command a volunteer battalion to France like the "Rough Riders," the volunteers he had led in the Mexican conflict of $1914 .{ }^{22}$ Others in the preparedness camp urged action to protect the cities of the east coast from marauding German submarines. The preparedness advocates argued vociferously that a resolution to the war could only come through American military strength. With uncertainty in the air, Wilson embarked on plans for implementing the preparedness program.

Songs from 1916, such as “On to Plattsburg, March!” and "Old Glory, a Song of Preparedness," record the preparedness movement. "On to Plattsburg" refers to the training camp for officers funded by preparedness advocates. The song may well have been used initially at the camp before finding a place in the public market. In fact, it is not just a song but also an instrumental march with a trio section that

\footnotetext{
${ }^{21}$ Kennedy, The Will to Believe, 6.

${ }^{22}$ No one argued that this would be a standing force; instead it would only be for use in the current conflict. Ibid., 7.
} 
includes lyrics. These lyrics aim to inspire men to conform to a soldier's duty, and they emphasize the significance of the country as Father, here denoted by the flag (Example 4). The sheet music is for piano with lyrics that are added above the staves in the trio section. In duple-triple meter, rather than a straight march, this song, written by Herbert W. Lowe, offers these patriotic words:

March on to Plattsburg, Swing into line and hike away

There's one place for us and that's Plattsburg

One time and that's today.

March on! Ev'ry road leads to Plattsburg,

Under the Flag, Glorious Flag, The Red, White and Blue!

This section is followed by a "Fife and Drum" march, an iconic sound of the infantry, during which the pianist is instructed to ad lib with his right hand. The piece creates the environment of a training camp a year before actual official training camps would be built and run by the government. A restlessness to enter the battle and undo the terrible disaster in Europe resonates in the patriotism of this line and military march of the music. Pacifists decried the preparedness programs; in their view, these programs only furthered the aims of wealthy citizens, who hoped to profit from the military development and, as one writer put it in 1916, "look[ed] down with undisguised contempt upon the masses."23

Example 4. "On to Plattsburg March!" (1916) by Herbert W. Lowe , words by David Stevens mm.22-29 of the Trio.
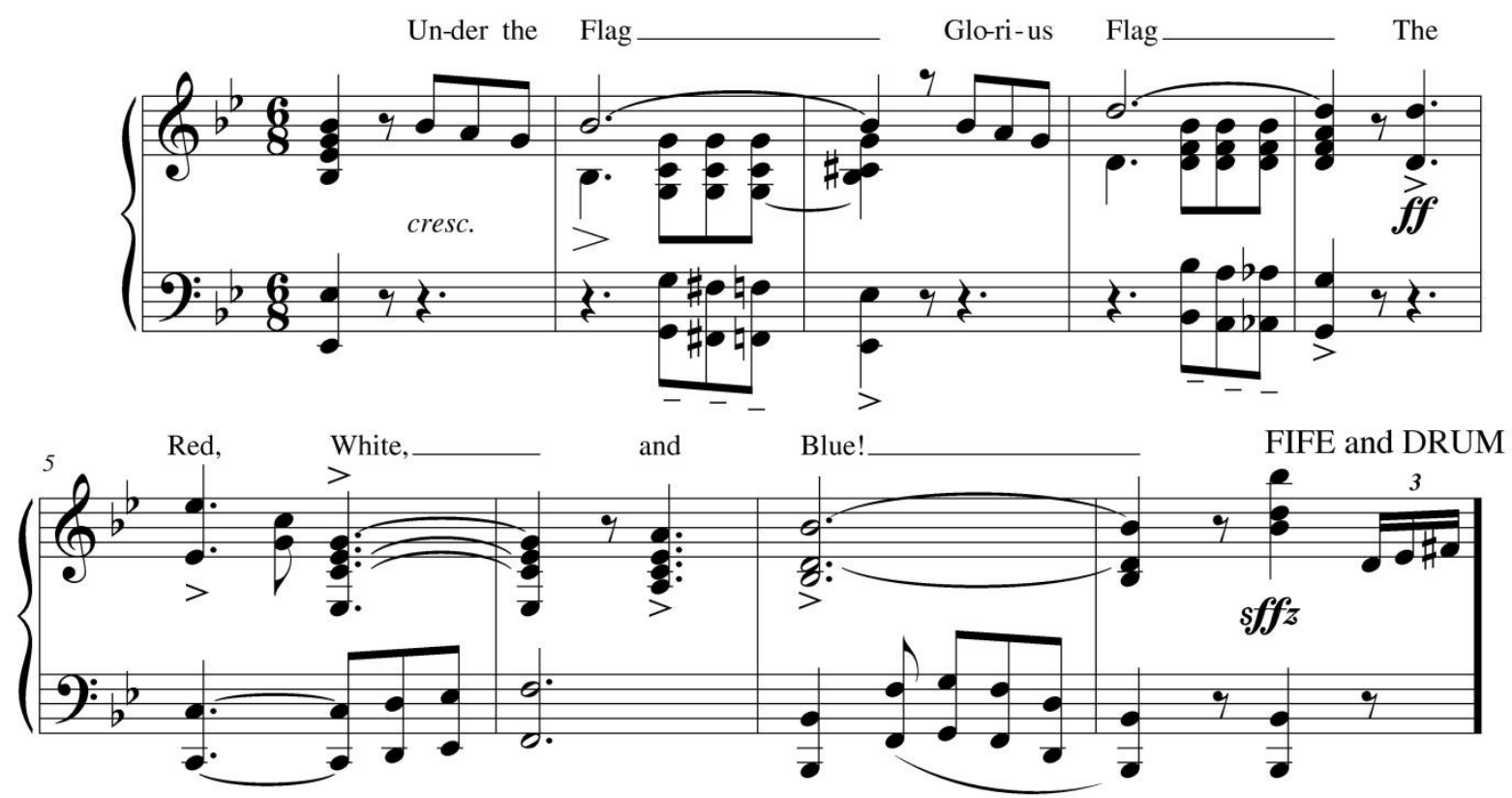

23 “Shall militarism devour the farm?” Commoner 16 (Jan. 1916): 3. Quoted in Kennedy, The Will to Believe, $2009,2$. 


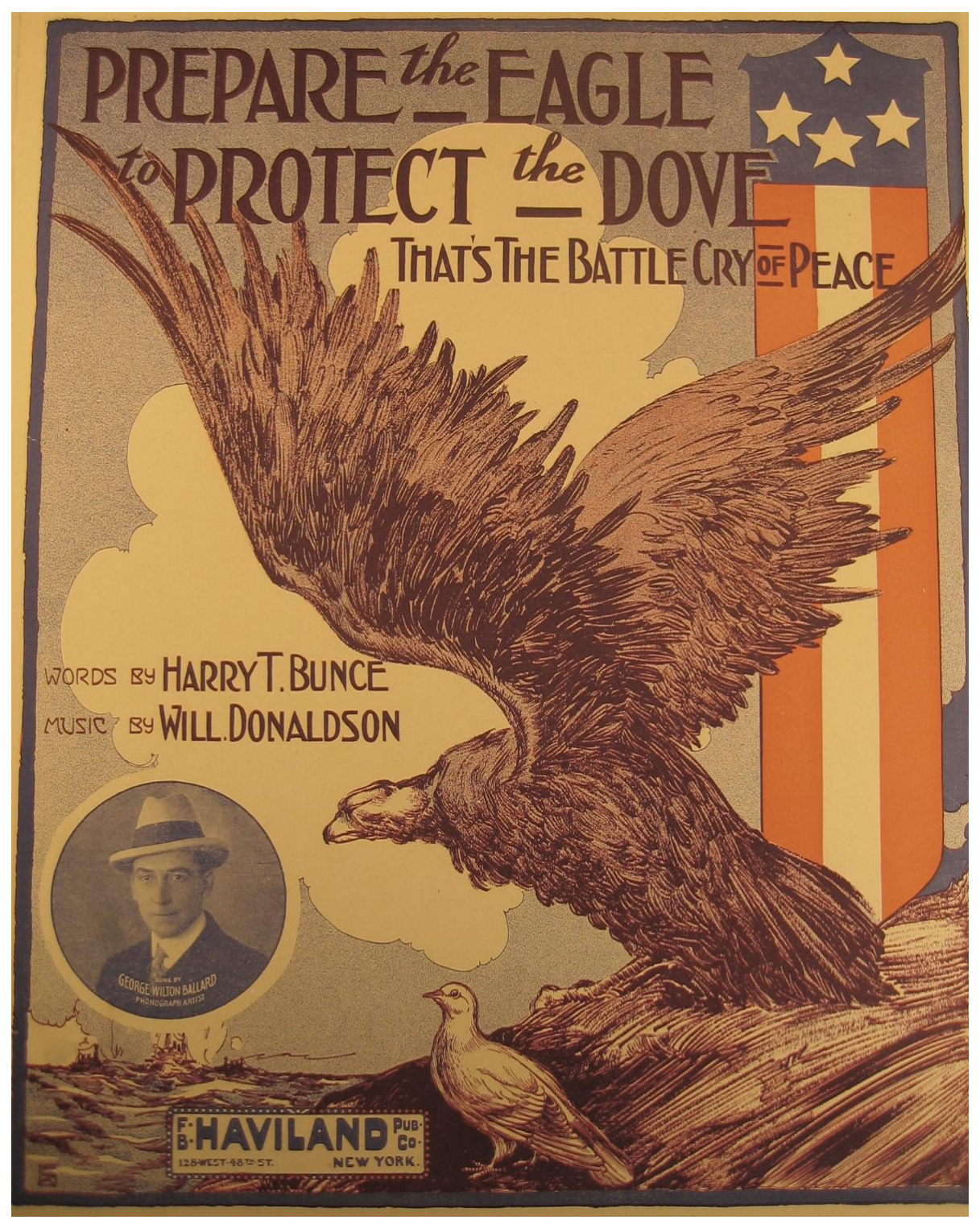

Figure 4. Cover to "Prepare the Eagle to Protect the Dove" (1916), a song in support of preparedness to maintain peace. 
The sheet music for the song "Old Glory, a Song of Preparedness" tries to refute this perceived "contempt" by being enthusiastically inclusive. It calls for a tempo of allegro marziale or a "martial allegro" and lays out the reasons everyone can be patriotic and prepare for war. The end of the first verse is remarkably all-encompassing for the era:

Men of every creed and color would be marching sided by side

For... if... old...Glory calls us all to arms our Country to defend

Then ev'ry man for Uncle Sam will

Fight unto the end.

Old Glory's call we will obey

And then in freedom's name

We'd sooner die [...]

Than see day Old Glory called in vain

The musical style aspires to be strict and martial, and the inclusiveness of the tone in the verse aims mainly to build obedience in the imagined army. Preparedness advocates rallied around the symbolism of the flag and how American freedom needed protection from German attack.

The 1916 song "Prepare the Eagle to Protect the Dove" is subtitled "That's the Battle Cry of Peace" (Figure 4). Preparedness advocates argued that only good training and the best weapons could hope to prevent an eventuality that would entail sending soldiers into battle "like sheep ... to be slaughtered," as one preparedness backer is quoted as saying. ${ }^{24}$ In this respect the two sides of the argument had the same aim, peace, and the trouble of protecting that peace is the concern of songwriters Harry T. Bunce and Will Donaldson. Gendered emblems mark the first verse, "America, America, you are the queen of earth." We can note that the trope of Mother as nation resonates here as it does in George McConnel's "Heart of this World," discussed above, but with a notably different effect. The Father symbol enters when the second verse refers to George Washington and attributes a quote that directly helps their cause,

Washington, Washington, the father of this land, In days of old with words of gold spoke to his valiant band[.]

"Be ready for all cruel war, and peace will reign supreme"

So let us respect it,

And always protect it,

And this must be our theme,

"Prepare the Eagle to Protect the Dove"

Is the battle cry of peace

In a steady duple meter, without chromaticism or modulation, this song is not excessively emotional in its musical style. Instead, it aims to present the most practical and balanced approach to the situation. The melding of gender symbols in this verse, with a feminine land and masculine leader, underscores the importance for this writer that his singers conceive of the strength of both together: peace only happens when mothers and fathers

${ }^{24}$ Zieger, America's Great War: World War I and the American Experience, 40. 
support a strong military. Ziegler describes the preparedness argument with some irony, "Only by preparing young men through military training and equipping them with the finest weapons could the nation avoid sending them." ${ }^{25}$ Even though Wilson won the election in 1916 in part by the slogan "He kept us out of the war!" the preparedness movement (which Wilson had helped plan) shifted from the sidelines to the mainstream in 1916. As Kennedy writes, "For the pacifists it followed that militarism was already engulfing America and undermining its democracy... by spring of 1916 Congress intensified the nation's 'militarist infection' [in pacifists' minds] by enacting most of Wilson's preparedness program." 26

Along with this political shift, several songs appear to have been produced specifically to contradict "I Didn't Raise My Boy to be a Soldier." In these songs the mother figure eventually shows satisfaction with soldiering and is dissuaded from her initial despair. The song "I'd be Proud to be the Mother of a Soldier" (1915) was written and composed by Charles Bayha, and the opening verse establishes the characters of Father, Mother, and Son. The first verse sings,

Seated around the table

Were Mother and Dad

And their darling lad,

He was all they had,

"It's not right that men should fight,"

He wisely shook his head,

"Each soldier brave, his nation's slave, goes out to die."

Interestingly, it appears that the son is the "wise" family member, who feels hesitant to become a soldier. The mother is also reticent about sending her son off, and she responds to her son,

You'd do the same thing [...] a' though you'd cause me sorrow

Just like your Dad before you[,] you'd march away to war [...]

I pray for peace[,] it's true

She admits she prays for peace but then the symbol of "Old Glory," or the nation, quickly persuades her to support her son's enlistment:

But it would be a different story

If they trampled on Old Glory [fermata]

I'd be proud to be a mother of a soldier

This song was published in 1915 one year after the war began and therefore much earlier than the events that would bring about the eventual American entrance. The symbolic icons of family and nation run through this song in quick eighth notes in stepwise motion, and the music does not offer many broader note values until the fermata pause after "Glory." The glory of the nation shifts the Mother's heart, and thus the national and the local are compellingly brought together in this song (Example 5). The publication of both "I Didn't Raise My Boy" and "I'd be Proud to be the Mother" in 1915 suggests how the disagreement in society was articulated through song around the idea of the family.

\footnotetext{
${ }^{25}$ Ibid., 140.

${ }^{26}$ Kennedy, The Will to Believe, 33.
} 
Example 5. "I'd Be Proud to Be a Mother of a Hero" (1915) by Charles Bayha, end of chorus.
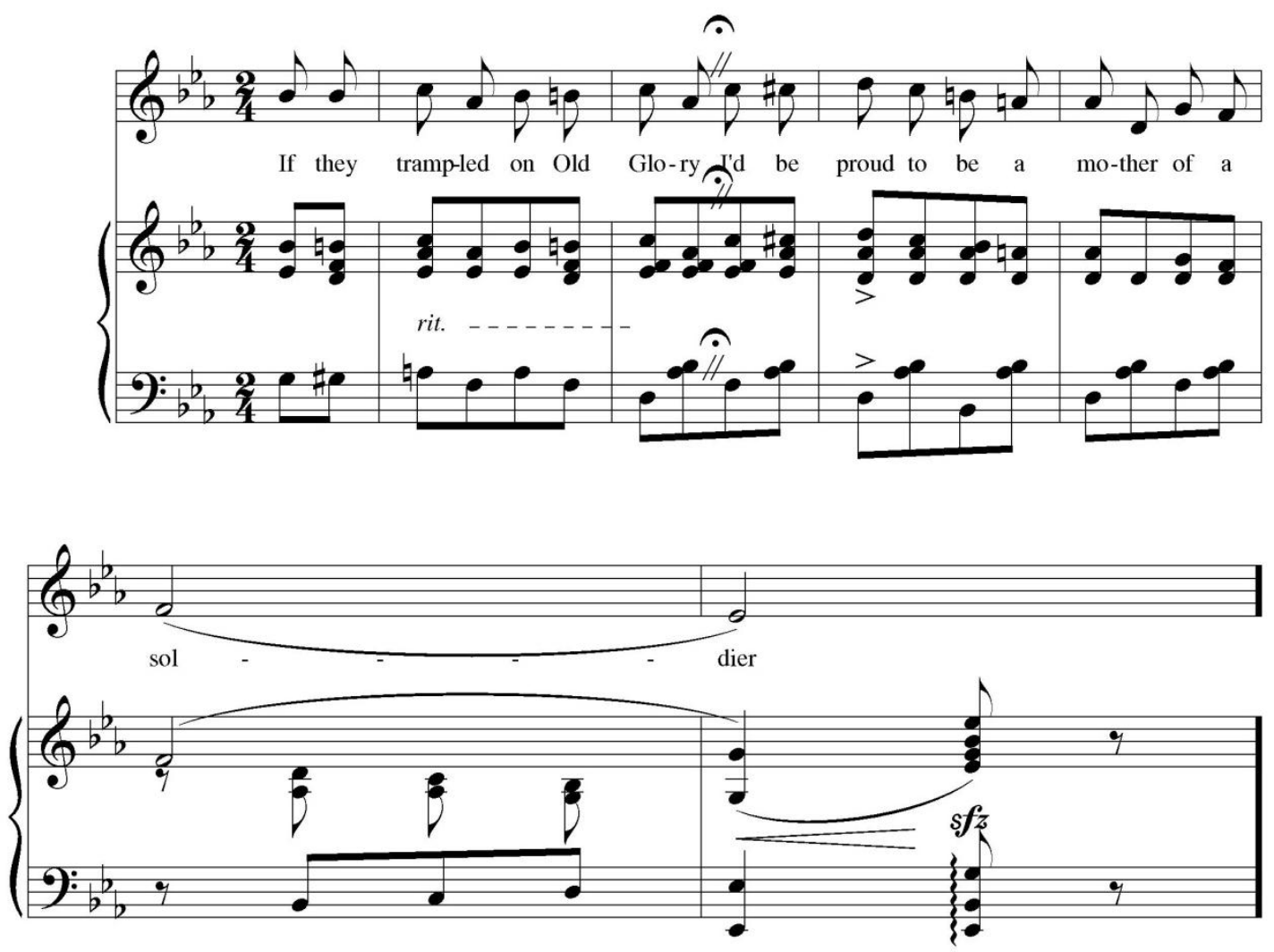

In 1918 a year after the U.S. had entered the conflict, Dr. C.F. Conrad and Dell Lampe wrote the song "I Tried to Raise My Boy to be a Soldier," in which a mother raises her boy to be a soldier after the "rape of Belgium by the Hun." Four years after the German attack on Belgium, the effect of this atrocity was still an important part of the popular reason for why the nation should be at war. ${ }^{27}$ The lyrics in the next stanza read, "She must forget that other song of yore, / She will proudly give her boy," where the "other song of yore" likely directly refers to "I Didn't Raise My Boy" from 1915. As all these songs show, the discourse of the military in sheet music worked directly through motherly emotions. The songs reflect different sides of the debate about war, and the lyrics work through shifts in the symbolic meanings of Mother and Father.

Despite the competing song titles, the song “I Didn't Raise My Boy to be a Soldier” reveals a general popular sentiment about the war from 1915 through April 1917. ${ }^{28}$ In the spring of 1917, the U.S. struggled to maintain its neutrality after the government intercepted the "Zimmerman telegram" to Mexico, and German submarines off the coast in the Atlantic continued to breach international agreements. In April 1917 when Wilson found neutrality untenable and asked Congress for a declaration of war against Germany, the pacifist songs lost their place in the market almost overnight as songs spreading the

\footnotetext{
${ }^{27}$ For example, the song "My Belgian Rose" from 1917 illustrates American pity for Belgium. Gier, "Gender, Politics, and the Fighting Soldier's Song in America During World War I," 8.

${ }^{28}$ Watkins, Proof through the Night: Music and the Great War, 249.
} 
excitement of enlistment were written. Songs such as George M. Cohan's "Over There" (1917), which promoted the American Expeditionary Forces (AEF), would overwhelm the market in the coming year.

However, this fact cannot mean that all Americans were suddenly comfortable with their country's new challenge; they certainly had to adapt to the new situation. The songs discussed here bring to life one way that ordinary Americans during the period from 1914 to 1917 tried to come to terms with the massive national and global changes of the First World War. By June 5, 1917, enlistment began, and by July all eligible men were called to serve in a formal drawing of lots. ${ }^{29}$ In 1917 two pieces of sheet music were published that clearly defined the tensions that remained over the American entry into war. The song "A Call to Arms," subtitled "The American Marseilles," specifies that it was written and published on April 7, 1917, the day of the official declaration. In a spritely tempo di Marcia, the lyrics repeat the government's call to war. In contrast, another piece of sheet music published in 1917 was entitled "A Call for Peace," a call that would not and could not be widely heard. The melody and lyrics are by Rose Hoeninghaus, and she poetically captures a mother's pain at the loss of a young son, who had "scarcely even seen a gun." It is mother-focused, with the words, "Oh Pray for Peace.... Throbs in my heart that mothers cry, I hear her weary cry..." She speaks to a very real loss that would occur for many mothers during the American involvement. In the end, these cries of course had little impact on the workings of the political forces that caused the growth of the military and sent the AEF to Europe. The process of compelling the public to support the American role in the war would be facilitated in 1918 by sheet music and by the Four Minute Men, groups of men and women trained to make the government's case for war in four-minute speeches presented in towns across the nation. ${ }^{30}$ As we see from the great amount of war-related sheet music published in 1917 and 1918, songs would prevail as one of the most widespread social mediums to reflect and shape the public response to the American efforts on the fields of France. ${ }^{31}$ In conclusion, the songs singing of pacifism and preparedness offer a view into the musical conversations Americans had around the piano before the U.S. entry into the war, and they indicate how those on the home front may have engaged in debates about of war apart from the major speeches by politicians. Despite some resolute

pacifists, the songs point to how the symbols of the family shifted in the public discourse from painting the Mother as a representative for peace to showing the joint resolve of both Father and Mother to fighting in the Great War.

\footnotetext{
${ }^{29}$ Alfred E. Cornebise, War as Advertised: The Four Minute Men and America's Crusade 1917-1918 (Philadelphia: The American Philosophical Society, 1984), 63.

${ }^{30}$ Ibid.

${ }^{31}$ Gier, "Gender, Politics, and the Fighting Soldier's Song in America During World War I."
} 


\section{Bibliography}

Chambers, John Whiteclay. To Raise and Army: The Draft Comes to Modern America. New York: The Free Press, 1987.

Cooney, Robert and Helen Michalowski. The Power of the People. Culver City, CA: Peace Press, 1977.

Cornebise, Alfred E. War as Advertised: The Four Minute Men and America's Crusade 1917-1918. Philadelphia: The American Philosophical Society, 1984.

Dudley, William, ed. World War I: Opposing Viewpoints. San Diego: Greenhaven Press, 1998.

Elshtain, Jean Bethke. Women and War. New York: Basic Books, 1987.

Farwell, Byron. Over There: The United States in the Great War 1917-1918. New York London: W.W. Norton and Company, 1999.

Furia, Phillip and Michael Lasser. America's Songs: The Stories Behind the Songs of Broadway, Hollywood and Tin Pan Alley. London, New York: Routledge, 2006.

Gier, Christina "Gender, Politics, and the Fighting Soldier's Song in America During World War I." Music and Politics 2, no. 1 (2008): online.

Jasen, David A. Tin Pan Alley: The Composers, the Songs, the Performers and Their Times. New York: Donald I. Fine, Inc., 2003.

Kennedy, David. Over Here: The First World War and American Society. New York: Oxford University Press, 1980.

Kennedy, Ross A. The Will to Believe. Kent, Ohio: Kent State University Press, 2009.

Laffin, John. Tommy Atkins: The Story of the English Soldier. Gloucestershire: Sutton Publishing Limited, 1966; 2004.

Parker, Bernard. World War I Sheet Music : 9,670 Patriotic Songs Published in the United States, 1914-1920, with More Than 600 Covers Illustrated. Jefferson, N.C.: McFarland, 2007.

Patterson, David S. "Citizen Peace Initiatives and American Political Culture, 1865-1920." In Peace Movements and Political Cultures, edited by Charles and Peter Van den Dungen Chatfield, 187-203. Knoxville: University of Tennessee Press, 1988.

Roell, Craig H. The Piano in America, 1890-1940. Chapel Hill: The University of North Carolina Press, 1989.

Tawa, Nicholas. The Way to Tin Pan Alley: American Popular Song, 1866-1910. New York: Schirmer Books, 1990.

Vogel, Frederick G. World War I Songs: A History and Dictionary of Popular American Patriotic Tunes with over 300 Complete Lyrics. Jefferson, NC and London: McFarland and Company, Inc., 1995.

Watkins, Glenn. Proof through the Night: Music and the Great War. Berkeley: University of California Press, 2003.

Zieger, Robert H. America's Great War: World War I and the American Experience. Lanham and New York: Rowman and Littlefield Publishers, 2000. 